Original Article

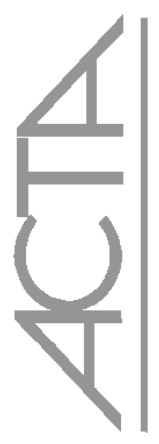

\title{
Influenza vaccination among nursing professionals: reality and challenges*
}

\author{
Vacinação contra Influenza em profissionais de enfermagem: realidade e desafios \\ Vacunación contra la influenza en profesionales de enfermería: realidade y desafíos
}

\author{
Raquel Heloisa Guedes Vieira ${ }^{1}$, Alacoque Lorenzini Erdmann², Selma Regina de \\ Andrade $^{3}$, Paulo Fontoura Freitas ${ }^{4}$
}

\begin{abstract}
Objective: To determine the profile, vaccination status and the motivating factors that lead nurses of a university hospital to get vaccinated against influenza in order to maximize coverage through adequate operational/educational strategies. Methods: Cross-sectional descriptive study with a sample size of 265 nurses. Results: Vaccination coverage was found to be $49.8 \%$ in 2009, 92.4\% in 2010 and $95.4 \%$ in 2011. The professional profile with better adherence to vaccination was the mid level, female, 41-50 years, separated/divorced, not living with people susceptible to influenza, except chronic patient, also with more than one employment bond, placed at emergency where they often have contact with patients, trained and working for over 20 years, vaccinated in their own work sector, motivated by self-protection. Conclusion: The coverage percentage of $92.5 \%$ in 2010 and $95.4 \%$ in 2011, were considered exceptional within the current global reality. Educational actions within the institution created an incorporated culture of biosafety related to the topic.
\end{abstract}

Keywords: Influenza vaccines; Nursing; Health knowledge, attitudes, practice; Health education

\section{RESUMO}

Objetivo: Determinar o perfil, a situação vacinal e os fatores motivadores que levam profissionais de enfermagem de hospital universitário a se vacinarem contra Influenza visando à maximização da cobertura por meio de estratégias operacionais/ educativas adequadas. Métodos: Estudo transversal descritivo com amostra de 265 profissionais de enfermagem. Resultados: A cobertura vacinal encontrada foi de 49,8\% em 2009, $92,4 \%$ em 2010 e 95,4\% em 2011. O perfil do profissional mais aderente à vacinação foi o de nível médio, feminino, 41-50 anos, separado/ divorciado, não co-habitante com susceptíveis à Influenza, exceto doente crônico, mais de um vínculo empregatício, lotado na emergência, contato frequente com pacientes, formado e trabalhando há mais de 20 anos, vacinado no próprio setor de trabalho, motivado por autoproteção. Conclusão: Os percentuais de cobertura de 92,5\%, em 2010, e de 95,4\%, em 2011, foram considerados excepcionais dentro da atual realidade mundial. Ações educativas criaram dentro da instituição uma cultura de biossegurança bem incorporada relacionada ao tema.

Descritores: Vacinas contra influenza; Enfermagem; Conhecimentos, atitudes e prática em saúde; Educação em saúde

\section{RESUMEN}

Objetivo: Determinar el perfil, la situación de las vacunaciones y los factores motivadores que llevan a los profesionales de enfermería de un hospital universitario a vacunarse contra la Influenza con el objetivo de lograr la máxima cobertura por medio de estrategias operacionales/ educativas adecuadas. Métodos: Estudio transversal descriptivo realizado con una muestra de 265 profesionales de enfermería. Resultados: La cobertura de vacunaciones encontrada fue del 49,8\% en el 2009, 92,4\% en el 2010 y 95,4\% en el 2011. El perfil del profesional más adherente a la vacunación fue el de nivel medio, femenino, 41-50 años, separado/divorciado, no cohabitante con susceptibilidad a la Influenza, excepto enfermo crónico, más de un vínculo laboral, repleto en la emergencia, contacto frecuente con pacientes, formado y trabajando hace más de 20 años, vacunado en el propio sector del trabajo, motivado por autoprotección. Conclusión: Los porcentajes de cobertura del 92,5\%, en el 2010, y del $95,4 \%$, en el 2011, fueron considerados excepcionales dentro de la actual realidad mundial. Las acciones educativas crearon dentro de la institución una cultura de bioseguridad bien incorporada relacionada al tema.

Descriptores: Vacunas contra la influenza; Enfermería; Conocimientos, actitudes y práctica en salud; Educación en salud

\footnotetext{
*Study conducted at the Federal University of Santa Catarina - UFSC - Florianopolis (SC), Brazil.

${ }^{1}$ Professional Master Care Management in Nursing, Federal University of Santa Catarina - UFSC - Florianopolis (SC), Brazil.

${ }^{2}$ PhD of Philosophy in Nursing. Professor of the Department and the Graduate Program in Nursing, Federal University of Santa Catarina - UFSC - Florianopolis (SC), Brazil.

${ }^{3}$ PhD in Nursing. Professor of the Department and the Graduate Program in Nursing, Federal University of Santa Catarina - UFSC - Florianopolis (SC), Brazil.

${ }^{4}$ PhD in Epidemiology. Professor of the Graduate Program in Medical Sciences, Federal University of Santa Catarina - UFSC - Florianopolis (SC), Brazil.
} 


\section{INTRODUCTION}

One of the diseases that brings increasing concern to society in general and healthcare institutions, in particular, is the Influenza. Serologic evidence suggests that $13 \%-23 \%$ of health workers are infected with influenza each year and that about $50 \%$ of those infected present only mild symptoms or are even asymptomatic, many remain working under this condition, which facilitates spreading ${ }^{(1)}$. The situation is a concern because this disease is recognized as a major cause of morbidity and mortality worldwide financial expenditures ${ }^{(2)}$.

In their daily work, nursing professionals are exposed to risks from diverse origens, including those from contact with biological agents harmful to their health. Biological risks of occupational origin have attracted more interest from researchers and they have highlighted the risks that professionals suffer when they do not adopt the use of preventive measures ${ }^{(3)}$. From this perspective, we must pay special attention to professionals who work in hospitals because they are more exposed in their daily lives to infectious diseases than the population in general, because, once infected they may sicken or, even not getting sick, transmit the infection to other professionals and patients within the institution, as occurs, for example, in influenza illness ${ }^{(4)}$. Nevertheless, these workers prevention adherence by influenza vaccination is only about $40 \%$ or less ${ }^{(5)}$. Within this segment, surprisingly, nursing professionals commonly have lower adherence rates ${ }^{(1,6-9)}$.

Since 2000, Influenza vaccine is annually offered for free to workers from the Polydoro Ernani São Thiago University Hospital of Federal University of Santa Catarina (UH/UFSC), including nursing. In order to significantly increase vaccination adherence, strategies have been relying on the tripod: dissemination, facilitated accessibility and continuing education, always seeking the best coverage for this disease. However, there was a need for objective data on the institutional reality, so that it could allow more effectively direct future actions. Thus, this study aimed to answer the questions: what is the profile of the vaccination status and the motivating factors that lead nurses at a university hospital to be vaccinated against influenza? How can immunization coverage be maintained and/ or improved based on these data?

\section{METHODS}

This descriptive cross-sectional study was conducted at the UH/UFSC located in Florianopolis (Santa Catarina), a tertiary hospital, which currently has 274 beds and a total of 1163 effective workers, allocated into four boards, one of which Nursing Board (NB). Nursing professionalsfrom the NB/UH/UFSC participated of the study, they were nurses, nursing technicians and nursing assistants, randomly elected and freely accepted to participate in the study by signing a Consent Form.

The determination of sample size was based on the Vaccination Campaign against H1N1 Influenza held in 2010 at theUH where the Auxiliary Personnel Department (APD) provided a list with 491 nursing staff effective workersallocated at the NB/UH/UFSC in the categories of nurses (135), nursing technicians (200) and nursing assistants (156). Professionals who were vaccinated at the $\mathrm{UH}$ and signed the list, received the qualification of "vaccinated". Those who had not been vaccinated in the $\mathrm{UH}$, and therefore without signature in the list, were given the preliminary classification of "unvaccinated". Based on statistical calculations to determine the sample size, and taking as reference the three categories and their vaccination status, we came to a total of 265 individuals ( 75 nurses, 108 nursing technicians and 82 nursing assistants). This sample was calculated to be sufficient to determine a $95 \%$ confidence the expected prevalence. Identified the 265 subjects in the sample, aform was applied with three determinants (identification data,professional dataand vaccination data), shortly after the campaign of 2010 .

Based on data collected, a database was created and its analysis was conducted using SPSS 18.0. Statistical analysis was considered statistically significant at $\mathrm{p}$ $<0.05$, with $95 \%$ confidence interval. This study is part of a research project "Vaccin situation against Influenza of nursing staff in a teaching hospital: diagnosis and interventions", of the Professional Master in Management of Nursing Care, approved by the Ethics Committee on Human Research of UFSC under No. 723 on $26 / 04 / 2010$.

\section{RESULTS}

From the 265 professionals surveyed, 159 had been vaccinated at the UH/UFSC in 2010, according to the list provided by the APD/UH/UFSC. When applying the questionnaires to the 106 professionals who were not vaccinated in the hospital, it was found that 86 of them had been vaccinated outside the institution. Thus, the actual vaccination coverage in 2010 was $92.4 \%$ (50.9\% in that institution and over $32.5 \%$ out of it). They were also asked if they had been vaccinated in the hospital or other institution in the year before the application of the questionnaire (2009), only 132/265 (49.9\%) said yes. From the 133 
who were not vaccinated in 2009, $113(85.0 \%)$ reported having received vaccination in 2010, and only 20 $(15.0 \%)$ remained without the vaccine. It is noteworthy that $100.0 \%$ of those vaccinated in 2009 were also vaccinated in 2010.

The 491 nursing staff workers previously mentioned, were followed during the 2011 Campaign. From these, 3.3\% were made redundant at the institution in the period between the two campaigns. From the 475 professionals who remained working in the institution, $62.9 \%$ were vaccinated in 2011 in the premises of the UH. Considering the plausible hypothesis that this year, the rate of vaccination in other health institutions, not in the UH/UFSC, was the same of $2010(32.5 \%)$, vaccination coverage in 2011 was $95.4 \%$ (62.9\% plus $32.5 \%)$.

The answers obtained by applying the questionaire indicated higher vaccination rate among females workers $(92.8 \%)$, who also were: separated/divorced (95.0\%); aged $41-50$ years (96,5\%); and did not live with children $(95.5 \%)$ or with seniors $(93.3 \%)$, but lived with chronic disease patients $(95.0 \%)$. Among them $92.6 \%$ had employment bond with another institution where they would work in the emergency $(94.9 \%)$ and had frequent contact with patients $(92.3 \%)$. Higher proportion of vaccinees was found among those with a degree for over 20 years $(94.9 \%)$ and among those, who also worked in the hospital for over 20 years $(94.0 \%)$.

From the 265 subjects in the sample, 159 were vaccinated during the campaign within the UH/UFSC in 2010 . Of these, the majority $(51.0 \%)$ in their own work sector by mobile teams that go around the hospital for this purpose. When questioned regarding the preferred location of vaccination, 128/245 (52.3\%) of vaccinated people said they preferred their own workplace. The percentage of vaccination coverage among technicians and nursing assistants $(93.5 \%$ and $93.9 \%$ respectively) were slightly higher than those observed among nurses (89.3\%). These sociodemographic and clinical variables when subjected to statistical tests showed no significance.

However, the opposite occurred when asked to indicate the reasons for justifying their vaccination (there was the possibility for more than one answer), the main reason mentioned by both vaccinated and unvaccinated people was self-protection $(96.3 \%$ and $55.0 \%$ respectively), followed by protection of their family $(85.3 \%$ among the vaccinated and $50.0 \%$ in the unvaccinated) and protection of patients (69.8\% of vaccinated and $40.0 \%$ of unvaccinated). The encouragement of colleagues, medical indication and the fact they were already vaccinated earlier did not appeare in both groups, as strong reasons to justify vaccination. (Table 1 ).
Table 1. Reasons which justifythe professional to get vaccinated, as vaccine coverage(vaccinated/unvaccinated) - UH/ UFSC, 2010

\begin{tabular}{|c|c|c|c|c|}
\hline \multirow{2}{*}{\multicolumn{2}{|c|}{$\begin{array}{l}\text { Reasons which justify } \\
\text { vaccination }\end{array}$}} & \multirow{2}{*}{$\begin{array}{c}\text { Vaccinated } \\
245 \\
n(\%)\end{array}$} & \multirow{2}{*}{$\begin{array}{c}\text { Unvaccinated } \\
20 \\
n(\%)\end{array}$} & \multirow{2}{*}{${ }_{\text {- value* }}^{\mathrm{p}}$} \\
\hline & & & & \\
\hline \multirow{2}{*}{$\begin{array}{l}\text { Patient`s } \\
\text { protection }\end{array}$} & Yes & $171(69.8)$ & $8(40.0)$ & \multirow[t]{2}{*}{0.008} \\
\hline & No & $74(30.2)$ & $12(60.0)$ & \\
\hline \multirow{2}{*}{$\begin{array}{l}\text { Had already } \\
\text { taken their } \\
\text { vaccine earlier }\end{array}$} & Yes & $20(8.2)$ & $2(10.0)$ & \multirow{2}{*}{0.511} \\
\hline & No & $225(91.8)$ & $18(90.0)$ & \\
\hline \multirow{2}{*}{$\begin{array}{l}\text { Encouragement } \\
\text { of colleagues }\end{array}$} & Yes & $33(13.5)$ & $2(10.0)$ & \multirow[t]{2}{*}{0.491} \\
\hline & No & $212(86.5)$ & $18(90.0)$ & \\
\hline \multirow{2}{*}{$\begin{array}{l}\text { Personal } \\
\text { protection }\end{array}$} & Yes & $236(96.3)$ & $11(55.0)$ & \multirow[t]{2}{*}{0.000} \\
\hline & No & $9(3.7)$ & $9(45.0)$ & \\
\hline \multirow{2}{*}{$\begin{array}{l}\text { Family } \\
\text { protection }\end{array}$} & Yes & $209(85.3)$ & $10(50.0)$ & \multirow[t]{2}{*}{0.000} \\
\hline & No & $36(14.7)$ & $10(50.0)$ & \\
\hline \multirow{2}{*}{$\begin{array}{l}\text { Medical } \\
\text { indication }\end{array}$} & Yes & $21(8.6)$ & $2(10.0)$ & \multirow[t]{2}{*}{0.536} \\
\hline & No & $224(91.4)$ & $18(90.0)$ & \\
\hline
\end{tabular}

* p significant at $95 \%$ confidence $(\mathrm{p}<0,05)$

\section{DISCUSSION}

The lack of statistical significance in collected sociodemographic and clinical data were due to unexpected small percentage of unvaccinated professionals in our final sample. However, the consistency in the direction of data allowed us to anticipate that the increase in the sample would maintain these results and it would show statistically significant values.

The data analysis from this study showed that vaccination coverage againstinfluenza among nursing professionals from the UH-UFSC in 2010 achieved an excellent mark of $92.4 \%$. Most professionals (59.9\%) received the vaccine within the institution, but also a large number $(32.5 \%)$ were vaccinated elsewhere. This coverage achieved in 2010 was significantly higher than that achieved in 2009 , when $49.8 \%$ of the nursing staff of the institution received immunization against influenza. It should be noted that the vaccination campaign, in 2009, was ended before schedule due to lack of vaccines, which certainly contributed to the decrease in coverage that year. Compared to 2011, the data showed that $62.9 \%$ of the nursing staff were vaccinated within the institution itself. Information on the percentage of vaccinated professionals in other institutions in 2011 is still being processed, but, if we project a similar percentage to 2010 (when $32.5 \%$ of the professionals were vaccinated outside the UH-UFSC), there is a percentage of coverage in 2011 of about $95.4 \%$. It is important 
to note that in 2009 , the vaccine offered for use in the hospital was the seasonal trivalent and in 2010, the pandemic monovalent. In 2011, the vaccine used in the campaign was the trivalent seasonal component with the pandemic included enlarging thus the spectrum of prevention.

Studies conducted in several countries have found low adherence toinfluenza vaccination. A study in Qatar found adherence rates reported by nurses from only $13.4 \%$ for the pandemic vaccine and $55.3 \%$ for the seasonal vaccine ${ }^{(10)}$. In Israel, the percentage of adherence stated, also among nurses, was only $34.1 \%{ }^{(11)}$. Research conducted in Australia found declared adherence rate of $48.4 \%$, still far from the minimum need for good protection and patient safety ${ }^{(12)}$. In Europe the situation is no different. In Spain ${ }^{(13)}$, a university hospital declared a percentage of $49.7 \%$ to the seasonal vaccine and $16.5 \%$ to thepandemic vaccine. In France, two oncology centers declared that thehealth professionals rate was $30.7 \%$ for the pandemic vaccine and $25.3 \%$ for the seasonal vaccine ${ }^{(14)}$. In the United States of America (USA), although the average percentage of adherence declared lies in $63.5 \%{ }^{(15)}$ in the $2010-2011$ season, some institutions had declared best toppings, such as the 94\% found among physicians at an university hospital in Pennsylvania ${ }^{(2)}$.

Based on these data, vaccination coverage was found to be higher than the world average. We must, therefore, study the reasons that contributed to that success. An important factor was probably the positive influence of media, as evidenced in the responses of the participants, during the Campaign of 2010. In Brazil, media emphasized the adverse consequences of the pandemic of 2009 and the protective benefits of the vaccine, motivating people towards vaccination in 2010 . In several countries, however, the media spread the idea that the vaccine had not been tested, and that it caused the disease rather than its prevention ${ }^{(13-14,16)}$. This would explain the difference in coverage with other countries, where the fear of the pandemic was not enough for these professionals to adhere to vaccination. In order to better measure media's influence, it is essential that other services do surveys and disclose their coverage rates. Thus, it will be possible to estimate the influence of local practices of each institution in rates of immunization coverage.

It was also highlighted that the small percentage of professionals who currently does not take vaccines, they do it due to very strong convictions, making a change in attitude towards vaccination very hard. It is also important to remember that many educational and accessibility actions were promoted from the first annual vaccination campaign occurred in 2000 at the $\mathrm{UH} / \mathrm{UFSC}$ and progressively increased over the decade.
These actions were focused on clarifying and guiding nursing workers for the benefits generated by vaccination, leading to the incorporation of positive attitudes and beliefs related to this preventive practice.

Therefore, considering that these hypotheses are not mutually exclusive, it is likely that there was a summation of them, which would explain both the significant increase occurred between 2009 and 2010, and also regarding the maintenance of the high level of vaccination coverage in 2011, including a small increase of 3.0\%.

Given these findings, and the goal of $80 \%$ vaccination recommended by the Brazil- Ministry of Health ${ }^{(17),}$ it can be stated that the coverage (confirmed/declared) found in nursing workers from NB/UH/UFSC was very high, hence emerging the challenge of how to maintain it or, ideally, increase it to even higher levels close to $100.0 \%$.

In this sense some findings such as gender, age, marital status, educational level, cohabitation with vulnerable people,institution working time, which are not modifiable by intervention procedures, but they can help direct specific educational programs to certain segments ${ }^{(18)}$. There is also data that although in principle not changeable by intervention programs, such as the workplace and their professional contact with the patient, may suffer educational initiatives that positively worked to bring clarification and direct behaviors that minimized the risk to the patient and professional under his care through vaccination.

Within this perspective, it was noted that special attention should be given to the younger age group $(\leq 30$ years), this study showed that their adherence to vaccination was lower $(89.4 \%)$, which corroborates data from research conducted in the U.S. ${ }^{(15)}$ which found higher Influenza vaccination coverage for people aged $\geq 60$ years. The positive association found in this study, longer time between professional and vaccination against influenza had also been observed previously ${ }^{(19)}$. In this perspective, investing in those with less time of graduation, the main current workforce of the $\mathrm{UH} /$ UFSC and that, in principle, remain longer in the institution, must be one of the goals of the educational measures that may be implemented. So, to clarify about various topics related to this theme, such as the indirect protection that vaccination Professional promotes in those who are admitted on condition of greater vulnerability may be configured in one of the strategies to be adopted ${ }^{(18,20-21)}$. Similarly, those who co-inhabit with children, the knowledge that can transmit the disease to them and they are more susceptible to complications ${ }^{(22)}$ can improve the adherence of vaccination.

This study also showed that among workers from the NB/UH/UFSC, the ones who were separated/ divorced more frequently responded to the vaccination 
call $(95.0 \%)$. Married people or people in a stable union were the ones who least accepted. Therefore, present and/or reinforce the knowledge that they can act as vectors of disease to their close relatives, may be one of the topics to be addressed in educational programs.

Those who had employment bonds with more than one health institution can benefit from the clarification about the most likely to acquire the virus, illness and/or contaminate the people in their social circle, including vulnerable patients in their care, motivating them to take a decision in favor of a greater adherence to vaccination.

A strong predictor of immunization is frequent contact with the patient ${ }^{(2)}$. This finding was corroborated in the current study in which $92.3 \%$ of nurses professionals who had frequent contact with patients during their hospital activities, were vaccinated.

However, this study, unlike the findings in the literature $^{(18-19)}$ shows that the higher level of education was the best predictor of adherence rates, the contrary was found here. Technicians and nursing assistants $(93.5 \%$ and $93.8 \%$, respectively) were vaccinated a little more than nurses $(89.3 \%)$. Whereas nurses are the natural leaders of the nursing team, being the heads and trendsetters, special educational measures should be directed to that category. It is important to remember that in this $\mathrm{UH} / \mathrm{UFSC}$ nurses are sectors heads, so we must think of strategies to improve knowledge on the subject in this segment, involving them, to act as motivators of this practice.

Still, when analyzing the reasons which justify being vaccinated, paradoxically there were no differences in motivation between groups of vaccinated and unvaccinated. Both groups agreed that self-protection, protection of the family and, finally, the protection of patients are the main reasons to get vaccinated differing only in percentages, enhanced in vaccinated people. Thus, we can say that knowledge does not necessarily affects the action. Other authors ${ }^{(20-23)}$ have also shown that the benefits of vaccination related to patients were little considered by some professionals, and which in this study also does not appear as the main motivators for vaccination. These data can be interpreted as a limited understanding of the benefits generated by vaccination in health professionalpresent, more intensely in those who have not adhered to this practice. In this sense, it is suggested that educational processes are emphasized concepts related to self-protection and the protection of the patient, eliminating misconceptions that may be related to the act of immunization ${ }^{(24)}$.

As for the operational strategies of vaccination, a study ${ }^{(25)}$ conducted with nurses from five U.S. healthcare organizations concluded by offering vaccines at various locations of the institution, as one of the actions that benefit the practice. In another study, the authors used different intervention strategies related to accessibility, including the training of workers to act vaccinating their colleagues in the workplace, prolongingvaccination time beyond the routine, mass vaccination day,mobile vaccinators moving aroud workplece which, combined with educational measures and diverse dissemination, obtained an increase of $77.0 \%$ to $84.7 \%$ in coverage of the institution $^{(26)}$. It is also important to remember that facilitating access to vaccination through measures such as increasing the number of days of the campaign, making it available within the various work shifts and leaving the option for the professional to vaccinate in the workplace or go to a fixed location with easy access are important strategies for acquiring adequate coverage $\mathrm{(15,21,23)}^{(2)}$

Nevertheless, isolated measures in campaigns involving only education or only promotionhave little impact on increasing adherence to vaccination. However, whenthese two actions are combined, education and promotion, with measures to facilitate accessibility to the vaccine, the results obtained are substantially better ${ }^{(27)}$.

Finally, it is important to emphasize that health services, and especially nursing, have increasingly sought to achieve a standard of excellence that meets not only the patient who seeks, but also the health professional who works there. One factor that contributes to the achievement of this desired pattern, is the Influenza vaccine coverage for these professionals. It is not enough to prevent disease and promote health, it is also necessary that professionals do not cause harm to the person in their care.

The act of getting vaccinated against influenza, besides being a personal act, is also a social act, because the protection afforded by that encompasses all people who live with the person who is vaccinated. Aware of this, healthcare institutions worldwide have sought to improve this vaccine coverage rates within themselves. In this sense, much has been done, but generally little has been achieved.

The University Hospital from UFSC, has annually offered, since 2000 , the influenza vaccine free of charge to their employees, including nursing. While, at the same time, they offer within their mission of teaching hospital, they also seek to educate on the importance and necessity of this act.

During these years, several actions to improve access to vaccine for workers, as vaccinating them in their workplace, making the vaccine available during all shifts and for more than a week, among others, have been performed and improved. Actions related to promotionis also continually being improved. Special attention to educational strategies that inform, guide and motivate professionals to adhere to this practice is a constant and should be improved with the subsidies provided by this study. 


\section{CONCLUSION}

This study found a coverage of nursing professionals vaccination in 2010 (confirmed/declared) of $92.5 \%$ and in 2011 (estimated) $95.4 \%$, exceptional within the current global reality. It was found that professionals that have better adherence to vaccination against influenza are: females, separated/divorced, aged $41-50$ years, who did not live with children and the elderly, but lived with people with chronic disease.Those withemployment bond with other institutions, working with emergency and have frequent contact with patients. Thosewho are trained and work in the hospital for over 20 years. We also found that these professionals are primarily motivated by self-protection, protection of patients and their families, and the challenge of keeping this adherence is related to the maintenance and improvement of the institutional culture of biosafety.

\section{REFERENCES}

1. Ofstead CL, Tucker SJ, Beebe TJ, Poland GA. Influenza vaccination among registered nurses: information receipt, knowledge, and decision-making at an institution with a multifaceted educational program. Infect Control Hosp Epidemiol. 2008;29(2):99-106..

2. deSante JE, Caplan A, Shofer F, Behrman AJ. Physician attitudes towards influenza immunization and vaccine mandates. Vaccine. 2010;28(13):2517-21.

3. Chiodi MB, Marziale MH. [Occupational risks for public health workers in Brazil: a systematic review of the literature. Acta Paul Enferm. 2006; 19(2):212-7. Portuguese.

4. Dinelli MI, Moreira TN, Paulino ER, da Rocha MC, Graciani FB, Moraes-Pinto MI. Immune status and risk perception of acquisition of vaccine preventable diseases among health care workers. Am J Infect control. 2009;37(10):858-60.

5. Joint Commission on Accreditation of Healthcare Organizations, Joint Commission Resources. Providing a safer environment for health care personnel and patients through Influenza vaccination: strategies from research and practice. Oakbrook Terrace (IL): Joint Commission Resources; 2009.

6. Martinello RA, Jones L, Topal JE. Correlation between healthcare workers' knowledge of influenza vaccine and vaccine receipt. Infect Control Hosp Epidemiol. 2003;24(11):845-7.

7. Trivalle C, Okenge E, Hamon B, Taillandier J, Falissard B. Factors that influence influenza vaccination among healthcare workers in a French geriatric hospital. Infect Control Hosp Epidemiol. 2006;27(11):1278-80.

8. Fanetti AC, Mascione R, Cecconi ER, Toia E, Tonelli F, Carrer P. [Influenza vaccination in health care workers of a university hospital in Milan]. G Ital Med Lav Ergon. 2007;29(3 Suppl):764-5.

9. Loulergue P, Moulin F, Vidal-Trecan G, Absi Z, Demontpion C, Menager C, et al. Knowledge, attitudes and vaccination coverage of healthcare workers regarding occupational vaccinations. Vaccine. 2009;27(31):4240-3.

10. Alkuwari MG, Aziz NA, Nazzal ZA, Al-Nuaimi SA. Pandemic influenza $\mathrm{A} / \mathrm{H} 1 \mathrm{~N} 1$ vaccination uptake among health care workers in Qatar: motivators and barriers. Vaccine. 2011;29(11):2206-11.

11. Shahrabani S, Benzion U, Yom Din G. Factors affecting nurses' decision to get the flu vaccine. Eur J Health Econ. 2009;10(2):227-31.

12. Seale H, Leask J, Macintyre CR. Awareness, attitudes and behavior of hospital healthcare workers towards a mandatory vaccination directive: two years on. Vaccine. 2011;29(21):3734-7.

13. Virseda S, Restrepo MA, Arranz E, Magán-Tapia P, Fernández-Ruiz M, de la Cámara AG, et al. Seasonal and Pandemic A (H1N1) 2009 influenza vaccination coverage and attitudes among health-care workers in a Spanish University Hospital. Vaccine. 2010;28(30):4751-7.
14. Barrière J, Vanjak D, Kriegel I, Otto J, Peyrade F, Estève M, et al. Acceptance of the 2009 A(H1N1) influenza vaccine among hospital workers in two French cancer centers. Vaccine. 2010;28(43):7030-4.

15. Centers for Disease Control and Prevention (CDC). Influenza vaccination coverage among health-care personnel --- United States, 2010--11 influenza season. MMWR Morb Mortal Wkly Rep. 2011;60(32):1073-7.

16. Seale H, Kaur R, Wang Q, Yang P, Zhang Y, Wang X, et al. Acceptance of a vaccine against pandemic influenza $A$ (H1N1) virus amongst healthcare workers in Beijing, China. Vaccine. 2011;29(8):1605-10.

17. Brasil. Ministério da Saúde. Informe Técnico. Campanha Nacional de Vacinação contra a Influenza 2011. Florianópolis. Brasília(DF): Ministério da Saúde; 2011. p. 1-22.

18. Looijmans-van den Akker I, Hulscher ME, Verheij TJ, Riphagen-Dalhuisen J, van Delden JJ, Hak E. How to develop a program to increase influenza vaccine uptake among workers in health care settings? Implement Sci [Internet]. 2011 [cited 2012 Out 20]; 6(47): Available from: http:/ /www. implementationscience.com/content/6/1/47.

19. Looijmans-van den Akker I, van Delden JJ, Verheij TJ, van Essen GA, van der Sande MA, Hulscher ME, et al. Which determinants should be targeted to increase influenza vaccination uptake among health care workers in nursing homes? Vaccine. 2009;27(34):4724-30.

20. Al-Tawfiq JA, Antony A, Abed MS. Attitudes towards influenza vaccination of multi-nationality health-care workers in Saudi Arabia. Vaccine. 2009;27(40):5538-41.

21. Chen SC, Hawkins G, Aspinall E, Patel N. Factors influencing uptake of influenza A (H1N1) vaccine amongst healthcare workers in a regional pediatric centre: lessons for improving vaccination rates. Vaccine. 2012; 30(2):493-7.

22. Newall AT, Scuffham PA. Influenza-related disease: the cost to the Australian healthcare system. Vaccine. 2008;26(52):6818-23

23. Gilbert GL, Kerridge I, Cheung P. Mandatory influenza immunisation of health-care workers. Lancet Infect Dis. 2010;10(1):3-5.

24. Blank DL, Bodansky DM, Forbes A, Garde E, Story F, Roalfe $\mathrm{AK}$, et al. Influenza vaccination of future healthcare workers: a cross-sectional study of uptake, knowledge and attitudes. Vaccine. 2010;28(29):4668-72.

25. Slavin KE. American Nurses Association's best practices in seasonal influenza immunization campaign. AAOHN J. 2008;56(3):123-8.

26. Hood J, Smith A. Developing a "best practice" influenza vaccination program for health care workers--an evidence-based, leadership-modeled program. AAOHN J. 2009;57(8):308-12.

27. Lam PP, Chambers LW, MacDougall DM, McCarthy AE. Seasonal influenza vaccination campaigns for health care personnel: systematic review. CMAJ. 2010;182(12):E542-8. 